\title{
THE EFFECTIVENESS OF GENERATING INTERACTION BETWEEN SCEMATA AND TEXT (GIST) TO TEACH WRITING VIEWED FROM STUDENTS' INTELLIGENCE
}

( An Experimental research at the Second Grade Students of English Teaching Department of IKIP PGRI Madiun in the Academic Year of 2010/2011)

\author{
Nuri Ati Ningsih, SPd, MPd.
}

Email: nuri_basir@yahoo.com

\begin{abstract}
The research method was quasi experimental research by using simple factorial design $2 \times 2$. The population in this research was the second grade students of English Teaching Department of IKIP PGRI Madiun. The writer used cluster random sampling to get the sample. It consists of 60 students which were divided into two classes, II D consisting 30 students as a control class and II B consisting 30 students as an experimental class. The instruments used to collect the data were writing test to get the score of writing skill. Documentation was used to get the data of students' intelligence. Before the instruments were used, the tryout was done to know the validity and readiability of instruments. The writer analyzed the data in term of their frequency distribution, normality, and homogeneity. Then, the data were analyzed by using multifactoral analysis $2 X 2$.The findings in this research lead to some conclusions: (1) GIST is more effective than DI for teaching writing; (2) The students having high intelligence have better writing skill than the students having low intelligence; and (3) There is an interaction between teaching strategies and students' intelligence for teaching writing. The effect of teaching strategies on the students'writing skill depends on the students'intelligence.
\end{abstract}

Key words: Teaching, Writing, GIST, Direct Instruction, Intelligence.

\section{INTRODUCTION}

In this research, the reseacher just focuses on the two teaching strategies, GIST (Generating Interaction between Scemata and Text) and Direct Instructional strategy (DI). The reason are first, both teaching strategies are applicable to be applied in teaching writing at the University, second, both of them have different perspective and principles in the process of teaching. The writer conducts an experimental research to investigate the effectiveness of GIST (compared with DI) in teaching writing viewed from students' intelligence. GIST is used as the independent variable in experimental group, whereas DI is in control group. Meanwhile, writing skill is placed as the dependent variable. 
This research tend to find out the difference between teaching strategies and which one is more effective in teaching writing for students who have high or low intelligence. The purposes of the research are: (1) to reveal whether GIST is more effective than Direct Instructional strategy to teach writing; (2) to reveal whether the students having high intelligence have better writing skill than those having low intelligence; (3) to prove out whether there is an interaction between teaching strategies and students' intelligence to teach writing.

Writing is a complex activity since it requires students' comprehensive abilities such as mastering grammar, vocabulary, and punctuation. Besides, to write well, the students are expected to be able to present their ideas in the written form as writing is a means of communication. However, some think that writing is not only delivering ideas to others but also using a sheer energy to complete the writing process itself: thinking the ideas, preparing the outline, transferring the outline into draft, revising the draft, and finally proofreading the draft to prepare for the final outcome.

Fegurson and Mickerson (1992: 7) state that writing is a skill that is acquired through study. Writing is one of English skills that should be taught integratedly, but it is regarded as the most difficult language skill to learn for learners. It is often perceived as the most difficult language skill since it requires a higher level of productive language control than the other skills.

The writing process has steps or procedures which must be carried out by the learners. According to Hoshima and Hogue (1997: 2) writing is never a onestep action; it is a process that has several steps. In other word, writing has more than one step. The steps in writing process are prewriting, planning, writing and revising draft, and writing the final copy to hand in. A good writing is done from a set of rules and principles.

Nunan (1991: 3) writes successful writing involves mastering the mechanics of letter formation and obeying conventions of spelling and punctuation, using the grammatical system to convey one's intended meaning, organizing content at the level ofparagraph and the complete text to reflect given/new information and topic/comment structures, polishing and revising one's initial efforts, and selecting an appropriate style for one's audience. It can be said that if students want to be successful in writing, they must do some steps, and each step involves the grammar rule, spelling, punctuation, how to organize content at the level of paragraph. Based on the theories of writing, it can be concluded that writing is the process of thinking to invent ideas, 
thinking about how to express into good writing, and arrange the ideas into statement and paragraph clearly. It indicates that the learners are expected to explore the ideas and make them into good paragraph. The indicator of the writing skill in this research is exploring the ideas and making them into good descriptive paragraph. The scoring is based on indicators of writing competence, namely organization, content, grammar, punctuation, spelling, mechanics, style, and quality of expression.

In this case, the researcher finds that many students of English Teaching Department of IKIP PGRI Madiun get some difficulties in writing. In fact, the students are not capable to make a good writing. The reason that they cannot make a good writing is caused by poor vocabulary, difficulty in generating their idea, poor grammar, and so on. To solve the problems as mentioned above, the teacher should be able to encourage the students to express their ideas into good writing. The lectures have to give opportunities to the students to write their ideas without being afraid of making mistake. It can be done by introducing topics and a good writing process.

Because of some problems above, the lecture of writing must have a variety of teaching strategies. One of them is GIST. Herrel and Jordan (2008: 272) say
GIST is a strategy for supporting comprehension of informal text. According to Richarrdson and Morgan (2000 : 1) GIST is a comprehension strategy that is used both during and after reading. Futhermore, Dahloan (2008: 2) GIST templates help students to get main idea and compherend the meaning of what someone has said or written. Therefore, it can be concluded that GIST is a kind of teaching reading strategy by activating the students' schemata for understanding and comprehending the content of the passage or text delivered by the authors. According to Schunder and Jackson (1989) GIST strategy teaches students to use prediction as a comprehension aid when reading expository text. The ability to predict what a passage will be about is often based on prior knowledge. According to Dahloan (2008 : 2) GIST strategy is especially useful when trying to teach main idea and supporting details. The lecture will find their students'ability to comprehend text and find the main idea increases. To reach the goal a GIST template or form should have the following basic information: Your prediction, the $5 \mathrm{~W}$ 's (Who, where, when, why what), and a final prediction.

In applying GIST to teach writing, the steps are as follows (1) identify the appropriate text (2) group the students consisting of a strong English speaker and reader, then, hand out the worksheet (3) 
demontrate the strategy by giving some instructions related to $5 \mathrm{~W}$ 's and $\mathrm{H}$ (instructions can be given for the group and individual basis) (4) have the students write the "GIST" of the article/ text in 20 words (5) discuss the summary of the text (6) read and summarize paragraph by paragraph (7) read and compare the summary and (8) assess students progress and understanding. The function of the text given by the lectures, in this case, is as a stimulus. It will stimulate the students to about the information will be writen. Then, there are some questions stated in the form of WH- Question to stimulate the students to make the outline of writing.

The difference between GIST and Direct Instructional Strategy can be seen from the learning activities done in the reading class. GIST (Generating Interaction between Scemata and Text) is a kind of teaching strategy that will make the students work cooperatively and develop their ability in their social and human relation. In GIST, students not only learn and receive whatever the teacher teaches in the teaching and learning process, but also learn from other students. The teaching learning process is students centered. Students have to be able to produce a limited words in the form of senteces based on their understanding on certain text given in group and present the result in front of the class. The result will determine the ability of the students in writing the text. In this case, the position of the lecture is as fasilitator and counselor. Meanwhile, Direct Instruction tends to teacher-centered. Lectures will guide the class activities intensively. The students will depend on the teachers' explanation to cacth the information stated in the text. This strategy does not allow the students to raise up their creativity and thinking process to solve the problem. This condition makes the students who have low intelligence will enjoy joining the reading class.

The other things that can influence the students' writing skill come from another aspect besides teacher's strategy. It is the student's intelligence. It is the power of one's intelect and as such is clearly a very important aspect of one's overall well-being. Moursund (1996: 1) composes the definition of intelligence based on various experts. Intelligence is the ability to: (1) Learn. This includes all kinds of informal and formal learning via any combination of experience, education, and training; (2) Pose problem.This includes recognizing problem situation and transforming them into more clearly

defined problem; (3) Solve problem. This includes solving problems, accomplishing task, fashioning products, and doing complex project. 
Boeree (2003: 1) describes an Intelligence Quotient (IQ) score gotten from an intelligence test as follows:

\begin{tabular}{cc}
\hline Score & Verbal information \\
\hline Under 7 & Mentally retarded \\
$70-80$ & Borderline retarded \\
$80-90$ & Low average \\
$90-110$ & Average \\
$110-120$ & High Average \\
$120-130$ & Superior \\
Over 130 & Very superior
\end{tabular}

\section{RESEARCH METHODOLOGY}

The population of the research was the second grade students of English Teaching Department of IKIP PGRI Madiun which consisted of seven classes. The sample, two classes which consisted of 60 students, was taken by using cluster random sampling. The sample was divided in two groups, experimental and control group. The experimental group was taught using GIST (Generating Interaction between Scemata and Text), while the control group was taught using Direct Instruction Strategy. In collecting the data, writing test and documentation were used. Before the instruments were used, a try out was done to know the validity and rediability of instruments. In analyzing the data, the reseacher used a descriptive analysis and inferential analysis in this research. Descriptive analysis was used to know the mean, median, mode, and standard deviation of scores of the writing test. Meanwhile, inferential analysis was used to test the research hypotheses. Inferential analysis used was ANOVA. Before conducting ANOVA, normality and homogeneity test were done to check normality and homogeneity of the sample distribution.

\section{RESULT AND DISCUSSIONS}

Hypothesis test can be done after the results of normality and homogeneity test were fullfill. The test is done by using multifactor analysis of variance $2 \times 2 . \mathrm{H}_{\mathrm{o}}$ is rejected if $F_{o}>F_{t}$, it means that there is a significant difference and an interaction. If $\mathrm{H}_{\mathrm{o}}$ is rejected, then the analysis is continued by using Turkey test. The multifactor analysis of variance $2 \times 2$ and Turkey test are described as below

\begin{tabular}{|l|r|r|l|l|l|}
\hline $\begin{array}{l}\text { Source } \\
\text { Variance }\end{array}$ & SS & df & MS & $\mathrm{F}_{0}$ & $\begin{array}{l}\mathrm{F}_{\mathrm{t}} \\
(0,05)\end{array}$ \\
\hline $\begin{array}{l}\text { Between } \\
\text { Columns }\end{array}$ & 453.75 & 1 & 453.75 & 7.33 & 4.016 \\
\hline $\begin{array}{l}\text { Between } \\
\text { Rows }\end{array}$ & 1416.25 & 1 & 1416.25 & 22.88 & \\
\hline $\begin{array}{l}\text { Columns } \\
\text { by Rows }\end{array}$ & 717.9167 & 1 & 717.9167 & 11.59 & \\
\hline $\begin{array}{l}\text { Between } \\
\text { Groups }\end{array}$ & 2587.917 & 3 & 862.6389 & & \\
\hline $\begin{array}{l}\text { Within } \\
\text { Groups }\end{array}$ & 3466.667 & 56 & 61.90476 & & \\
\hline Total & 6054.584 & 59 & & & \\
\hline
\end{tabular}

Table 1. Multifactor Analysis of Variance 
Table 2. Table of Mean Score

\begin{tabular}{|l|l|l|l|}
\hline & TAI & DIM & \\
\hline $\begin{array}{l}\text { High } \\
\text { Interest }\end{array}$ & 82.33 & 78.33 & 80.33 \\
\hline $\begin{array}{l}\text { Low } \\
\text { Interest }\end{array}$ & 65.33 & 77.33 & 68.50 \\
\hline & 77.17 & 72.16 & \\
\hline
\end{tabular}

From the computation result of ANOVA test, it can be infered that:

a. Because $F_{0}$ between columns (7.33) is higher than $\mathrm{F}_{\mathrm{t}}(0,05)$ (4.016), $\mathrm{H}_{0}$ is rejected and the difference between columns is significant. It can be concluded that the models used differ significantly from one another in their effect on their performance of the subjects in the experiment class. The students' mean of $\mathrm{c}_{1}$ (77.17) is higher than the students' mean of $\mathrm{c}_{2}$ (71.50), so the students who are taught by using GIST are better in writing skill than students who are taught by using Direct Instruction.

b. Because $F_{0}$ between rows (22.88) is higher than $\mathrm{F}_{\mathrm{t}}{ }_{(0,05)}$ (4.016), $\mathrm{H}_{0}$ is rejected and the difference between rows is significant. It can be concluded that the difference between the achievement of those subjects having high intelligence and those having low intelligence is significant. The students' mean of $r_{1}$ (80.33) is higher than the students' mean of $r_{2}$ (68.33), so the students who have high level of intelligence have better writing skill than the students who have low intelligence.

c. Because $F_{0}$ interaction (11.59) is higher than $\mathrm{F}_{\mathrm{t}(0,05)}(4.016), \mathrm{H}_{0}$ is rejected and it can be concluded that there is an interaction between the two variables, the teaching strategies and the level of intelligence to teach writing. It means that the effect of the teaching strategies used on the the students' achievement depends on the level of intelligence.

Tukey test is done by dividing the difference between the means by the square root of the ratio of the within group variation and the sample size.

Table 2. Tukey test

\begin{tabular}{|c|c|c|}
\hline PAIR & TUKEY & CRITICAL \\
\hline $\mathrm{A}_{1}-\mathrm{A}_{2}$ & 4.68 & 2.89 \\
\hline $\mathrm{B}_{1}-\mathrm{B}_{2}$ & 9.33 & 2.89 \\
\hline $\mathrm{A}_{1} \mathrm{~B}_{1}-\mathrm{A}_{2} \mathrm{~B}_{1}$ & 3.05 & 3.01 \\
\hline $\mathrm{A}_{1} \mathrm{~B}_{2}-\mathrm{A}_{2} \mathrm{~B}_{2}$ & 3.15 & 3.01 \\
\hline
\end{tabular}

From the result of TUKEY test, it can be infered that:

1) Comparing two means between columns $\left(A_{1}\right.$ and $\left.A_{2}\right) . q_{0}$ is 3.27. The value of $\mathrm{q}_{\mathrm{t}}$ for $\alpha=0.05$ and $\mathrm{n}=30$ is 2,89. Because $\mathrm{q}_{0}$ (4.68) is higher than $\mathrm{q}_{\mathrm{t}}$ (2.89) GIST differs significantly from Direct instruction for teaching writing. The mean score of students who are taught by using GIST is (77.17). It is 
higher than that of those who are taught by using Direct Instruction (71.50), so GIST is more effective than Direct Instruction.

2) Comparing two means between rows $\left(\mathrm{B}_{1}\right.$ and $\left.\mathrm{B}_{2}\right)$. $\mathrm{q}_{0}$ is 9.33 . The value of $\mathrm{q}_{\mathrm{t}}$ for $\alpha=0.05$ and $n=30$ is 2.89. Because $\mathrm{q}_{0}$ (9.32) is higher than $\mathrm{q}_{\mathrm{t}}$ (2.89) the students who have high intelligence in writing differs significantly from students who have low intelligence in writing. The mean score of students having high intelligence is (80.33) is higher than those who have low intelligence (68.33), so the students who have high intelligence in writing have better writing skill than the students who have low intelligence.

3) Comparing two means between cells $\left(A_{1} B_{1}\right.$ and $\left.A_{2} B_{1}\right) \cdot q_{o}$ is 3.05. The value of $\mathrm{q}_{\mathrm{t}}$ for $\alpha=0.05$ and $\mathrm{n}=15$ is 3.01 . Because $\mathrm{q}_{\mathrm{o}}$ (3.05) is higher than $\mathrm{q}_{\mathrm{t}}$ (3.01) GIST differs significantly from Direct Instruction for teaching writing for students having high intelligence. The mean score of students having high intelligence who are taught by using GIST (82.33) is higher than those who are taught by using Direct Instruction (78.33), so GIST is more effective than Direct Instruction for teaching writing for students having high intelligence.

4) Comparing two means between cells $\left(A_{1} B_{2}\right.$ and $\left.A_{2} B_{2}\right)$ is $q_{0}(3.15)$. The value of $\mathrm{q}_{\mathrm{t}}$ for $\alpha=0.05$ and $\mathrm{n}=15$ is 3.01 . Because $\mathrm{q}_{0}$ (3.15) is higher than $\mathrm{q}_{\mathrm{t}}$ (3.01), Direct Instruction differs significantly from GIST to teach writing for students who have low intelligence. The mean score of students having low intelligence who are taught by using Direct Instruction (71.33) is higher than those who are taught by using GIST (65.33), so Direct Instruction is more effective than GIST for students having low intelligence.

5) Based on the result of point 3 and 4, $\left(\mathrm{A}_{1} \mathrm{~B}_{1}\right.$ and $\left.\mathrm{A}_{2} \mathrm{~B}_{1}\right)$ and $\left(\mathrm{A}_{1} \mathrm{~B}_{2}\right.$ and $\left.\mathrm{A}_{2} \mathrm{~B}_{2}\right)$, GIST is more effective for teaching writing for students having high intelligence and Direct Instruction is more effective for students having low intelligence, it can be concluded that there is an interaction between the teaching strategies and the student's learning intelligence in teaching writing.

According to the research findings, it can be said that GIST is more effective than Direct Instruction to teach writing. The result of the first hypothesis test shows that GIST is more effective than Direct Instruction to teach writing for the second semester students of the English Teaching Department of IKIP PGRI Madiun. In GIST, the lecturer does not conduct the class conventionally. In this 
class, lecturer tries to conduct the writing class interactively. Lecturer guides the class by making the students to be able to interact with others. Making the students to interact with people around (the other students and lecturer) is as one of the characteristics of GIST. Doing the task in group can support each others. Every student has a different responsibility and they have to be able to present and share the result in the form of group discussion. The students not only learn and receive whatever the lecturer teaches in the teaching learning prosess, but also learn from other students. In other words, the students are demanded to be more active in joining the learning process. In short, GIST requires students to be able to work in groups cooperatively.

The lecturer fasilitates the students with the suitable text as a stimulus in an interesting package and create the active classroom activities in conducting the writing class. The lecturer stimulates the students to activate their previous knowledge. To support the classroom activities, the lecturer gives the students special reading exercises. The specific thing in this case is by combining $5 \mathrm{~W}$ 's question to make a summary of a certain reading text. Dahloan (2008: 1) says to reach the goal a GIST template or form should have the following basic information: Your prediction, the $5 \mathrm{~W}$ 's (who, where, when, why what), and a final prediction. It is intended to make the students easy to dig up their background of knowledge and write some words in in the form of sentences based on the text. In conclusion, GIST in the process of teaching writing gives the students good way how to explore their writing skill.

On the other hand, Direct Instruction strategy is less effective to improve the students'writing skill since the lecturer gives less motivation to the students to involve in their teaching learning process. In this case, the students just become the followers of the class activities and depend on the lecturer's guide during the teaching learning process. It is because Direct Instructionis teacherdirected and fast-paced, using a highly structured presentation of antecedents and consequences (Gersten, Woodward, and Darch (1986: 17-31). So, it can be concluded that GIST is better than Direct Instructin to teach writing.

The students who have high intelligence have better writing skill than those who have low intelligence. The students having high level of intelligence do well in their accomplishments, try hard and try to be successful in writing class. They also have a large recall of varied information and are quick to access it. As a result, the students with high intelligence generally enjoy a great deal of teaching and learningreading 
activities. Accordding to Ricky Andromeda (1999: 1) People with high IQ scores often have encyclopedic knowledge, above-average memory and calculation abilities. They process information much, much faster than the average person. On the other hand, the students having low intelligence tend to expect the worst, exert less effort on their reading tasks, especially challenging, demanding ones, and achieve less success in reading classroom activities. They find some difficulties to recall their prior knowledge to support them in understanding the content of the text.This situation is supported by Richard Nilsen (2011: 1) It is written that child who has a lower than average IQ begins with walking and talking later than his contemporaries. Other signs include poor social skills in play-learn situations with other children, delayed self-care, hygiene, dressing and feeding skills. As the child grows older, difficulties in learning academic skills and poor job skills may also be indicators. Therefore, the students who have high intelligence have better writing skill than the students who have low intelligence. There is interaction effect between teaching strategies and students' intelligence on the students' writing skill.

The result of the third hypothesis shows that there is interaction between the two variables, teaching strategies and the students' intelligence level to teach writing for the second semester students of English Department of IKIP PGRI Madiun. It means that the effect of teaching strategy on the students' reading skill depends on the students' intelligence. In this research, according to Herrell (2008: 272) GIST is an effective strategy for use with English language learners because the group members have a chance to discuss and clarify meaning as they decide on the best summary sentence for section or paragraph.

\section{CONCLUSION, IMPLICATION, AND SUGGESTION}

Based on the research findings, it can be concluded that the use of GIST (Generating Interaction between Scemata and Text) is more effective than Direct Instruction to teach writing. The students having high intelligence have better writing skill than the students having low intelligence and there is an interaction between teaching strategies and students' intelligence for teaching writing. GIST is suitable for students having high intelligence and DI is suitable for students having low intelligence. Therefore, it can be said that there is an interaction between teaching strategies applied by teachers and students' intelligence in teaching writing. In other words, the effectiveness of 
teaching strategies depends on the level of students' intelligence.

Research findings imply that the use of GIST can affect the students' writing ability maximally. It is proved from the research finding which shows that the students who are taught by using GIST have better writing ability than the students who are taught by using Direct Instruction. This condition can support the students to improve their writing skill. There are so many factors having by GIST that make the students succeed in attending the class of writing. GIST emphazises on exploring the students' prior knowledge to construct the new sentences based on the text given. It's also activate the students to work in group. Besides that, the level of the students' intelligence is one of the aspects which supports the students in writing. The students who have high intelligence have better writing skill than those who have low intelligence. It is because the students who have high intelligence supposed to read and write well than the students who have low intelligence. The students with high intelligence tend to get the information given much, much faster than the average person.

The result of research is that there is an interaction. So, the reseacher recommends to use GIST and Direct Instruction to teach writing.

Based on the conclusions and implications above, there are some suggestions proposed: (1) for teachers/ lecturers, it is important for the lecturer to improve the students' writing skill at college and apply GIST in their writing class and it is suggested to be more creative and innovative in using various kinds of teaching strategies so that the students will be interested and encouraged to attend the class, (2) for students, students are suggested to apply GIST in their writing process and to write more by applying GIST in order that their writing abillity will increase, and (3) for future researchers, for the future reseachers who intend to conduct the similar research in detail, the writer hopes that this research findings can be used as a reference for the next research.

\section{REFERENCES}

Arends Richard I, (1997)). Classroom Instruction and Management, USA. McGraw_Hill Companies.

Arthur Aron, (2011), Statistics, USA. Prentice Hall Inc.

Ary Donald, at al (2006). Introduction to Research in Education, USA, Wadsworth.

Boeree, George C. Intelligence and IQ in http:// webspace .ship.edu/cghoer /intelligence .html.

Brown, Douglas H, (2004), Language Assessment, USA, San Francisco State University

Dahloan in http:// www. associatedcontent. $\mathrm{com} / \mathrm{shared} /$ print. shtml?content_type $=$ ar 
Darley John, et al, (1986), Psychology, USA, Prentice-Hall Inc.

Furqon, PHd (2008). Statistik dalam Penelitian, Bandung, IKAPI.

Gall Meredith D., at al (2007). Educational Research; Introduction. USA. Pearson Education, Inc.

Gersten, Woodward, \& Darch, (1986) in http: //www. txautism. net/ docs /Guide/ Interventions/ Direct Instructions. Pdf

Harmer, Jeremy. (1998). How to Teach English. Edinburgh Gate, Harlow, Essex CM20 2JE. England.

Herrell, Andrienne L, (2008), Strategies for Teaching English Language Learners, Pearson Merrill Prentice Hall.

http://fcit.vsf.edu/fcat8r/home/references/p rintable-materials/ teachingstrategies.pdf

http://www.njcu.edu/CILL/vol7/andres.ht $\mathrm{ml}$ assessed on Desember 25, 2011.

http://www.macalester.edu/psychology/wh athap/ubnrp/intelligence 05

http://otec.uoregon.edu/intelligence.htm

http ://education. calumet. purdue. edu/ vockell/ edpsybook/ edpsy2/ edpsy2_direct. Htm

http: // www. interlakes. org /ilhs/ AV? D? GIST $\% \quad 20$ reading $\% 20$ strategies. Pdf

Spencer Kagan in http://www.

teachnology.

com/currenttrends/cooperative_ learning/ kagan/

Kauchak Donald P , (2007). Learning and Teaching , Researh-Based Methods, USA, Pearson Education.

Littlewood, William T. (1998). Foreign and Second Language Learning. New York: Cambridge University Press.

Logsdon, Ann, Overview of Intelligence Testing in http://learning disabilities.about.com/od/glossar1 /a/intelligencetes.htm.

McMillan.James.H. (1992). Educational Research Fundamental for Consumer.USA.Harper Collin. Publisher.

Moore, Moore, Cunningham, \& Cunningham. (1994) in www .trihellis .net/ assets/files/ strategies/gist.pdf

Ngadiso. (2006). Statistik, UNS

Nunan, David. (2003). Practical English Language Teaching. Mc Graw Hill Companies

Ormrod Jeanne Ellis, (2009), Essentials of Educational Psychology, USA, Pearson Education.

Richards, Jack C. (2001). Curriculum Development in Language Teaching. United State of America: Cambridge University Press.

Rothstein, R. Pamenal. (1990). Educational Psychology. Singapore: Mc Graw - Hill, Inc

Suharsimi Arikunto, (1998). Dasar-dasar Evaluasi Pendidikan (edisi revisi) Jakarta Bumi Aksara.

Santrock, John W. (2006). Human Adjusment. Boston: McGraw-Hill.

Thomas K et al, (1997), Educational Psychology, New York, Brown \& Benmark.

Urgurhart. Peny.(1996). A Course in language Teaching. New York . Cambridge University Press.

Williams, Marion and Burden, Robert L. (1997). Psychology for Language

Teachers: a Social Constructivist Approach. New York: Cambridge University Press.

Woolfolk, Anita. (2007). Educational Psychology. 10th ed. USA , Pearson Education, Inc. 
